Environment Conservation Journal 20 (1\&2) 41-46, 2019

ISSN 0972-3099 (Print) 2278-5124 (Online)

Abstracted and Indexed

\title{
Assessment of suitability of ground water quality in and around Laksar, Haridwar, Uttarakhand on the basis Water Quality Index (WQI)
}

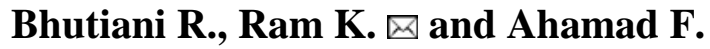

Received: 28.09 .2018

Revised: 28.12 .2018

Accepted: 14.03.2019

\begin{abstract}
The aim of present study is to assess the quality of the groundwater at selected villages of Laksar Block on the basis of Water Quality Index (WQI). During the present study maximum value of TS $(790.6 \pm 28.26 \mathrm{mg} / \mathrm{l})$ was found at site S1, while the minimum value $(705.3 \pm 5.59 \mathrm{mg} / \mathrm{l})$ was found at site $S 4$. The maximum average value of $\mathrm{TDS}(548.7 \pm 30.37 \mathrm{mg} / \mathrm{l})$ was found at site $S 5$, while the minimum value $(352.8 \pm 5.59 \mathrm{mg} / \mathrm{l})$ was found at site $S 4$. The maximum average value of $\mathrm{pH}$ (7.8 \pm 0.58$)$ was found at site $S 1$, while the minimum value $(6.9 \pm 0.70)$ was found at site $S 6$. The maximum average value of DO (6.5 \pm 0.57$)$ was $\mathrm{mg} / \mathrm{l}$ found at site $\mathrm{S4}$, while the minimum value $(6.1 \pm 0.57) \mathrm{was} \mathrm{mg} / \mathrm{l}$ found at site $\mathrm{S6}$. The maximum average value of TH $(396.9 \pm 65.94)$ was $\mathrm{mg} / \mathrm{l}$ found at site $\mathrm{S3}$, while the minimum value of TH $(223.3 \pm 5.59 \mathrm{mg} / \mathrm{l}) \mathrm{was}$ found at site S4. The maximum average value of $\mathrm{CaH}(331.3 \pm 32.57 \mathrm{mg} / \mathrm{l})$ was found at site $\mathrm{S} 1$, while the minimum value of $\mathrm{CaH}$ $(142.4 \pm 2.88 \mathrm{mg} / \mathrm{l})$ was found at site $\mathrm{S} 4$. The maximum average value of Chloride $(137.3 \pm 8.72 \mathrm{mg} / \mathrm{l})$ was found at site $\mathrm{S} 1$, while the minimum Chloride average value $(53.4 \pm 2.83 \mathrm{mg} / \mathrm{l})$ was found at site $\mathrm{S} 4$. The maximum value of Sulphate $(45.11 \pm 0.78 \mathrm{mg} / \mathrm{l})$ was found at site $S 5$, while the minimum value $(28 \pm 2.24 \mathrm{mg} / \mathrm{l})$ was found at site $S 4$.
\end{abstract}

Key words: Drinking water quality, Industrialization, Physico chemical, WQI.

\section{Introduction}

Water is an essential component of the planet earth, required for every physical and physiological activity of plants and animals. Without water life is not possible on the earth. Water is one of the five elements of the universe. Origin and evolution of life on planet earth is most intimately linked with water. It is the most abundant and essential compound in all the living systems. The amount of water in living organisms constitutes approximately $60-99 \%$ by weight and is an internal medium for all biochemical reactions. It is a principal ingredient for photosynthesis and plays a vital role in food production in plants as well as in animals. About 97\% of the total water present on the earth (1400 million billion), is not usable for drinking purpose due to saline nature. Only $3 \%$ of the total water is available as fresh water, out of which $2 \%$ of water is lodged in the polar ice caps and glaciers, only $1 \%$ water is available for portable use (WHO, 2004). Out of the total fresh water present on the earth

\section{Author's Address}

Limnology and Ecological Modelling Lab. Department of Zoology \& Environmental Sciences, Gurukula Kangri Vishwavidyalaya, Haridwar - 249404 , Uttarakhand, India. E-mail.: khushiram2013@gmail.com maximum quantity is used in irrigation sector (Bhutiani et al., 2018). The precipitation is the principal source of all water supplies on the earth. After precipitation some amount of water infiltrates into the soil and some amount of water moves over the surface as runoff. Groundwater plays a vital role in the life of both animals and plants in both drinking and irrigation purpose. It occurs under the surface of the earth in thousands of local aquifer systems and compartments that have similar characters and not in a single widespread aquifer.

Both the quality and quantity of groundwater are equally important because both are the major factors in determining the suitability of groundwater for drinking, domestic, irrigation industrial purposes. Groundwater contamination may occur by both natural factors and anthropogenic activities such as weathering of rocks, ore formation and leaching or due to increased population, industrial activities, urbanization, exploration, agricultural practices and exploitation of natural resources (Akinmosin et al., 2009). Around $80 \%$ of the diseases and deaths in the developing countries are related to water contamination (UNESCO, 2007). Water pollution 
not only affects water quality but also threats the human health, economic development, and social prosperity (Milovanovic, 2007).

The availability of good quality water is an indispensable feature for preventing diseases and improving quality of life. It is necessary to know about different Physico-chemical, heavy metal and microbiological characteristics of water before it is used for different purposes (Kolhe and Shinde, 2014). The easy availability of water depends on the depth of water table which normally decreases in summer when demand for water is at its maximum (Bhutiani et al., 2018).

\section{Materials and Methods}

Study area: Laksar block is an administrate part of district Haridwar. The average height of Laksar block from sea level is 745 feet and it is located between the towns of Khanpur and Sultanpur and close to the towns of Pathri, Jhabrera and Roorkee in Haridwar district (Fig 1. and Table 1). Peoples of the study area mostly depend on farming profession and the crops grown in the study area are sugar cane, wheat, paddy, barley and maize.

The groundwater samples were collected from all sites in the jerry cans of 2 liters capacity using Grab sampling from May, 2017 to January, 2018. The collected samples were analyzed for various physico-chemical parameters as per the standard methods described in APHA, 2012; Trivedy and Goel, 1986 and Khanna and Bhutiani, 2008. All the sampling sites were shown in figure 1 .

Table 1. Sampling locations different sites

\begin{tabular}{|l|c|c|c|}
\hline SN & Name of the site & Latitude & Longitude \\
\hline S1 & Laksar & $29^{\circ} 45^{\prime} 13.8348^{\prime \prime} \mathrm{N}$ & $78^{\circ} 1^{\prime} 17.3352^{\prime \prime} \mathrm{E}$ \\
\hline S2 & AkaudhaAurangzebpur & $29^{\circ} 44^{\prime} 42.3924^{\prime \prime} \mathrm{N}$ & $78^{\circ} 3^{\prime} 3.3408^{\prime \prime} \mathrm{E}$ \\
\hline S3 & Raisi & $29^{\circ} 41^{\prime} 58.0128^{\prime \prime} \mathrm{N}$ & $78^{\circ} 4^{\prime} 49.17^{\prime \prime} \mathrm{E}$ \\
\hline S4 & Niranjanpur & $30^{\circ} 17^{\prime} 50.6436^{\prime \prime} \mathrm{N}$ & $78^{\circ} 0^{\prime} 36.4068^{\prime \prime} \mathrm{E}$ \\
\hline S5 & KharanjaKutubpur & $29^{\circ} 43^{\prime} 51.6936^{\prime \prime} \mathrm{N}$ & $78^{\circ} 2^{\prime} 33.846^{\prime \prime} \mathrm{E}$ \\
\hline S6 & DabkiKalan & $29^{\circ} 44^{\prime} 29.256^{\prime \prime} \mathrm{N}$ & $78^{\circ} 0^{\prime} 39.5136^{\prime \prime} \mathrm{E}$ \\
\hline
\end{tabular}

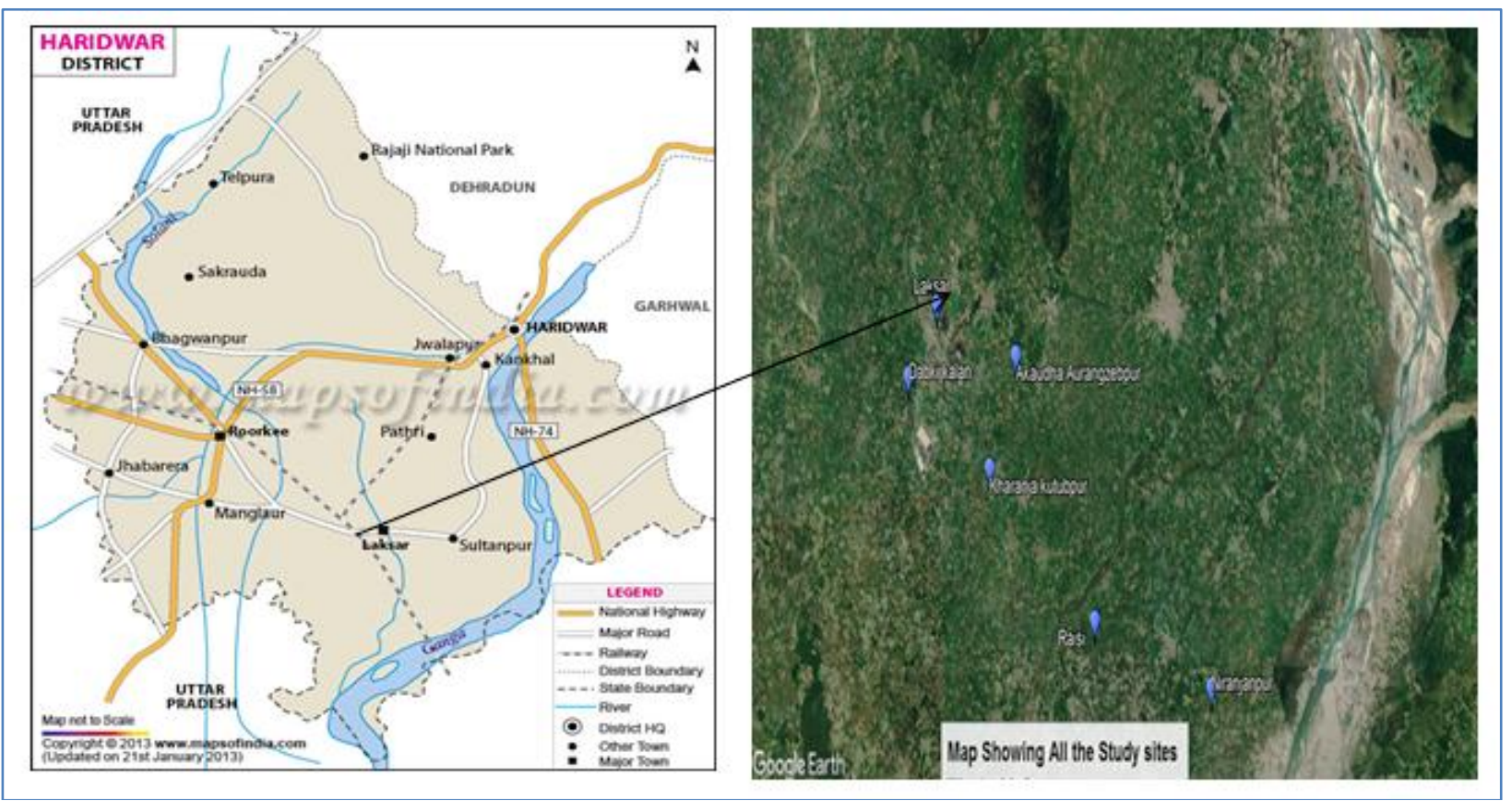

Fig 1. Showing Sampling Location in and around Laksar. 


\section{Water Quality Index (WQI)}

Water Quality Index (WQI) is a very useful and efficient method, which can provide a simple indicator of water quality and it is based on some important parameters. In current study WQI was calculated by using the Weighted Arithmetic Index method of Cude, 2001 and Brown et al., 1970. In this model, different water quality components are multiplied by a weighting factor and are then aggregated using simple arithmetic mean. For assessing the quality of water firstly, the quality rating scale (Qi) for each parameter was calculated by using the following equation-

Where,

$$
Q i=\frac{V o-V i}{V s-V i} \times 100
$$

Qi $=$ Quality rating of $i^{\text {th }}$ parameter for a total of $n$ water quality parameters

Vo $=$ Observed value of the water quality parameter obtained from laboratory analysis

$\mathrm{Vi}=$ Ideal value of that water quality parameter can be obtained from the standard Tables.

$\mathrm{Vi}$ for $\mathrm{pH}=7$ and for other parameters it is equal to zero, but for DO Vi $=14.6 \mathrm{mg} / \mathrm{L}$

$\mathrm{Sn}=$ Recommended $\mathrm{WHO}$ standard of the parameter.

Then, after calculating the quality rating scale (Qi), the Relative (unit) weight (Wi) was calculated by a value inversely proportional to the recommended standard $(\mathrm{Sn})$ for the corresponding parameter using the following expression-

Where,

$$
W i=\frac{K}{X i}
$$

$\mathrm{Wi}=$ Relative (unit) weight for nth parameter

$\mathrm{Xi}=$ Standard permissible value for $n$th parameter

$\mathrm{K}=$ Proportionality constant.

That means, the Relative (unit) weight (WI) to various water Quality parameters are inversely proportional to the recommended standards for the corresponding parameters.

Finally, the overall WQI was calculated by aggregating the quality rating with the unit weight linearly by using the following equation-

Where,

$$
W Q I=\frac{\sum Q i W i}{\sum W i}
$$

$\mathrm{Qi}=$ Quality rating

$\mathrm{Wi}=$ Relative (unit) weight
In general, WQI is defined for a specific and intended use of water. In this study the WQI was considered for human consumption or uses and the maximum permissible WQI for the drinking water was taken as 100 score table 2.

Table 2. Water Quality Index (WQI) and its status according to Chaterjee and Raziuddin (2002).

\begin{tabular}{|l|l|}
\hline $\begin{array}{l}\text { Water quality } \\
\text { Index Level }\end{array}$ & Water Quality Status \\
\hline $0-25$ & Excellent water quality \\
\hline $26-50$ & Good water quality \\
\hline $51-75$ & Poor water quality \\
\hline $76-100$ & Very poor water quality \\
\hline$>100$ & Unsuitable for drinking \\
\hline
\end{tabular}

\section{Results and Discussion}

The average results of various physico-chemical parameters analyzed during the study period such as Total Solid (TS), Total dissolved solids (TDS), $\mathrm{pH}$, Dissolved Oxygen (DO), Total Hardness (TH), Calcium Hardness $(\mathrm{CaH})$, Chloride $(\mathrm{Cl})$, and Sulphate $\left(\mathrm{SO}_{4}\right)$ and their WQI values was tabulated in table 3.

Total Solids: During the present study maximum TS value was found $(790.6 \pm 28.26 \mathrm{mg} / \mathrm{l})$ at $\mathrm{S} 1$ site while the minimum TS value was found $(705.3 \pm 5.59 \mathrm{mg} / \mathrm{l})$ at site $\mathrm{S} 4$ and the average value was found $(764.05 \pm 30.54 \mathrm{mg} / \mathrm{l})$ (Table 4). Similar results were reported by Bhadja and Vaghela, 2013.

Total Dissolved Solids (TDS): Total dissolved solids comprise inorganic salts principally calcium, magnesium, potassium, sodium, bicarbonates, chlorides, and sulphates and some small amounts of organic matter that are dissolved in water. Palatability decreases and may cause gastrointestinal irritation in humans. During the present study maximum value of TDS was found $(548.7 \pm 30.37 \mathrm{mg} / \mathrm{l})$ at site $\mathrm{S} 5$, while the minimum value was found $(352.8 \pm 5.59 \mathrm{mg} / \mathrm{l})$ at site $\mathrm{S} 4$ and the average value was found $(511.18 \pm 30.77 \mathrm{mg} / \mathrm{l})$. Similar results were reported by Kumar et al., 2017 and Bhutiani et al., 2018.

pH: During the study maximum value of $\mathrm{pH}$ was found $(7.8 \pm 0.58)$ at $\mathrm{S} 1$ site, while the minimum value was found $(6.9 \pm 0.70)$ at site $\mathrm{S} 6$ and the $\mathrm{pH}$ average value was found (7.1 \pm 0.35$)$. Similar trend was found by Saxena and Saxena, 2015. 
Bhutiani et al.

\begin{tabular}{|c|c|c|c|c|c|c|c|c|c|c|c|c|}
\hline \multirow[t]{2}{*}{ Parameters/ Sites } & \multicolumn{2}{|l|}{ S-1 } & \multirow{2}{*}{$\begin{array}{l}\text { S-2 } \\
\mathrm{OV}\end{array}$} & \multirow[b]{2}{*}{ WQI } & \multirow{2}{*}{$\begin{array}{l}\text { S-3 } \\
\mathrm{OV}\end{array}$} & \multirow[b]{2}{*}{ WQI } & \multirow{2}{*}{$\begin{array}{l}\text { S-4 } \\
\mathrm{OV}\end{array}$} & \multirow[b]{2}{*}{ WQI } & \multirow{2}{*}{$\begin{array}{l}\text { S-5 } \\
\text { OV }\end{array}$} & \multirow[b]{2}{*}{ WQI } & \multirow{2}{*}{$\begin{array}{l}\text { S-6 } \\
\text { OV }\end{array}$} & \multirow[b]{2}{*}{ WQI } \\
\hline & $\mathbf{O V}$ & WQI & & & & & & & & & & \\
\hline Total Solids (TS) & 790.6 & 0.0526 & 777 & 0.0518 & 760.1 & 0.0506 & 705.3 & 0.0470 & 780.9 & 0.0520 & 770.4 & 0.0513 \\
\hline Total Dissolved Solids (TDS) & 539.9 & 0.6591 & 541.7 & 0.6613 & 548.1 & 0.6692 & 352.8 & 0.4307 & 548.7 & 0.6700 & 535.9 & 0.6542 \\
\hline pH & 7.8 & 65.0185 & 7.1 & 8.1273 & 7.4 & 32.5092 & 6.9 & -8.1273 & 7.07 & 5.6891 & 6.9 & -8.1273 \\
\hline Dissolved Oxygen (DO) & 6.2 & 49.6046 & 6.2 & 49.6046 & 6.2 & 49.6046 & 6.5 & 47.8393 & 6.2 & 49.6046 & 6.1 & 50.1951 \\
\hline Total Hardness (TH) & 381.8 & 1.29916 & 377.7 & 1.2851 & 396.9 & 1.3506 & 223.3 & 0.7598 & 380.78 & 1.2956 & 377.7 & 1.2811 \\
\hline Calcium Hardness (CaH) & 331.3 & 17.9461 & 327 & 17.7159 & 326.4 & 17.6850 & 142.4 & 7.7154 & 330 & 17.8800 & 329.1 & 17.8260 \\
\hline Chloride (Cl) & 137.3 & 0.6650 & 119.1 & 0.5769 & 61.6 & 0.2983 & 53.4 & 0.2586 & 114 & 0.5521 & 125 & 0.6055 \\
\hline \multirow[t]{2}{*}{ Sulphate (SO4) } & 40.2 & 0.3057 & 42.4 & 0.3224 & 42.1 & 0.3201 & 28 & 0.2129 & 45.11 & 0.6937 & 40.22 & 0.3058 \\
\hline & \multicolumn{2}{|c|}{ WQI- 135.55} & \multicolumn{2}{|c|}{ WQI- 78.35} & \multicolumn{2}{|c|}{ WQI- 102.49 } & \multicolumn{2}{|c|}{ WQI- 49.14} & \multicolumn{2}{|c|}{ WQI- 76.44 } & \multicolumn{2}{|c|}{ WQI- 62.79} \\
\hline
\end{tabular}

Table 3. Sample showing observed values and WQI

WQI- Water Quality Inde, OV-Observed Values of the parameters

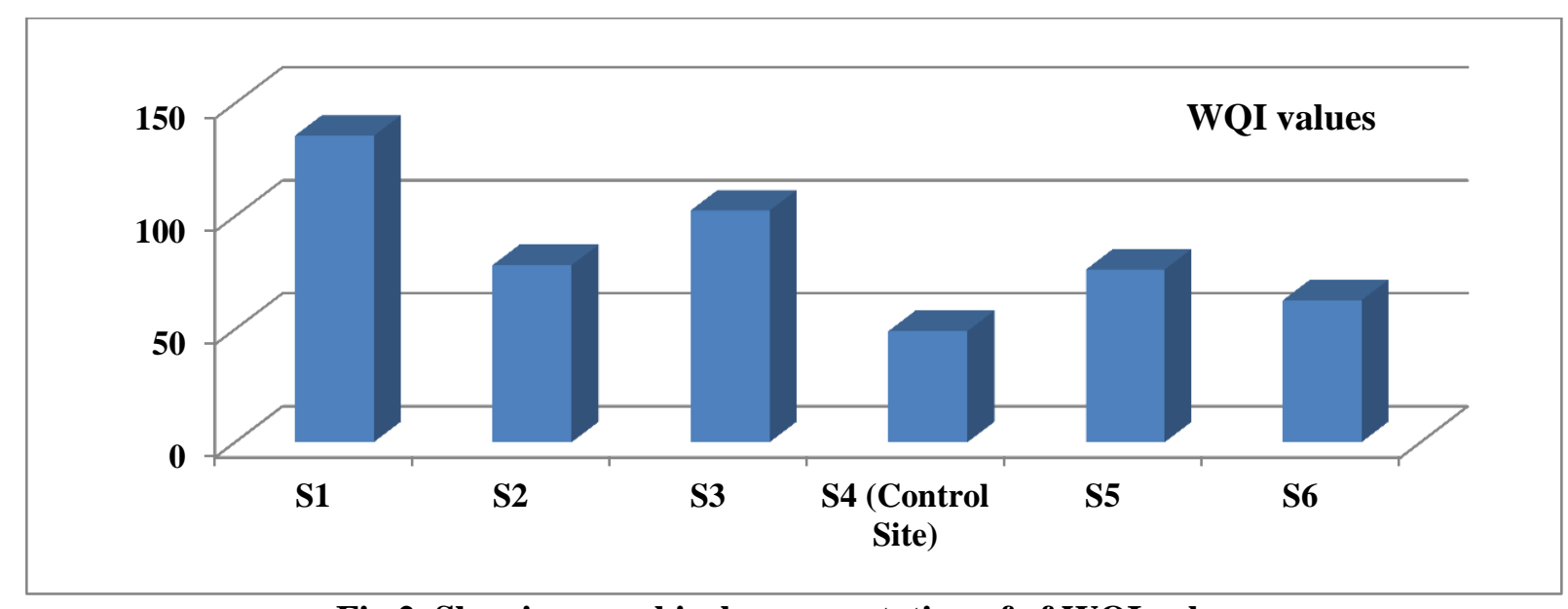

Fig 2. Showing graphical representation of of WQI values.

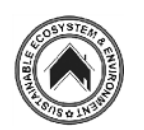


Dissolved Oxygen (DO): During the present study maximum DO value was found $(6.5 \pm 0.57 \mathrm{mg} / \mathrm{l})$ at site $\mathrm{S} 4$, while the minimum value was found $(6.1 \pm 0.57 \mathrm{mg} / \mathrm{l})$ at site $\mathrm{S} 6$ and DO average value was found $(6.2 \pm 0.14 \mathrm{mg} / \mathrm{l})$. Similar trend was found by Jai et al., 2014.

Total Hardness: Hardness is the ability of water to cause precipitation of insoluble $\mathrm{Ca}$ and $\mathrm{Mg}$ salts of higher fatty acids from excessive soap consumption Affect water supply system during the present study maximum $\mathrm{TH}$ value was $(396.9 \pm 65.94 \mathrm{mg} / \mathrm{l})$ found at site $\mathrm{S} 3$, while the minimum value of $\mathrm{TH}$ $(223.3 \pm 5.59 \mathrm{mg} / \mathrm{l})$ was found at site $\mathrm{S} 4$ and the $\mathrm{TH}$ average value was found $(365.36 \pm 65.58 \mathrm{mg} / \mathrm{l})$ Table 4. Similar results were reported by Ramakrishnaiah et al., 2009.

Calcium Hardness (CaH): During this study maximum value of $\mathrm{CaH}(331.3 \pm 32.57 \mathrm{mg} / \mathrm{l})$ was found at site $\mathrm{S} 1$, while the minimum value of Calcium Hardness $(142.4 \pm 2.88 \mathrm{mg} / \mathrm{l})$ was found at site S4 and total $\mathrm{CaH}$ value was found (297.7 $\pm 76.10 \mathrm{mg} / \mathrm{l})$ Table 4. Similar results were reported by Shankar, 2007.

Chloride (Cl): Chloride occurs naturally in all types of water. The high concentration of chloride is considered injurious to some people suffering from diseases of kidneys Taste, indigestion, corrosion and palatability are affected (Khan et al., 2012). during the present study maximum Chloride value $(137.3 \pm 8.72 \mathrm{mg} / \mathrm{l})$ was found at site $\mathrm{S} 1$, while the minimum Chloride value $(53.4 \pm 2.83 \mathrm{mg} / \mathrm{l})$ was found at site $\mathrm{S} 4$ and the Chloride average value was found $(101.73 \pm 35.23 \mathrm{mg} / \mathrm{l})$ Table 4. Similar trend was found by Saxena and Saxena, 2015.

Sulphate $\left(\mathbf{S O}_{4}\right)$ : During the present study maximum value of $\mathrm{SO} 4(45.11 \pm 0.78 \mathrm{mg} / \mathrm{l})$ was found at site $\mathrm{S} 5$, while the minimum value $(28 \pm 2.24 \mathrm{mg} / \mathrm{l})$ was found at site $\mathrm{S} 4$ and total SO4 value was found $(39.67 \pm 6 \mathrm{mg} / \mathrm{l})$. Table 4 Similar trend was found by Mandloi, 2014.

Water quality index value of of all the study sites were also calculated using weighted arithmetic index method. Village Niranjanpur (S4) was taken as control for the whole study because the anthropogenic activity was found very less as compared to other study villages. The water quality index rating of the study site S1, S2, S3, S4, S5 and S6 was $135.55,78.35,102.49,49.14,76.44$, and 62.79 respectively. The values when compared with criteria described by Chaterjee and Raziuddin
(2002), depicted in the table 2 shows that none of the site fall in the category of excellent water quality (0-25) even the control site water quality falls in the category of good water quality (26-50). Site $\mathrm{S} 6$ falls in the category of poor water quality (50-75) while S5 and S2 falls in the category of very poor water qulity (75-100). Site S1 and S3 falls in the category of unsuitable for drinking (more than 100). The WQI value of the study area suggests that the ground water quality of the study area is vey poor and in some areas unsuitable for drinking purpose (Table 3 and Fig 2). The depleted water quality in the study area may be due to industrial acitivity as a number of industries whether seasonal and full time are running in the study area and releasing their solid and liquid waste whether treated or partially treated on the ground. The burying of the solid waste in the ground cause ground water depletion because of leachate.

\section{Conclusion}

During the present study we found that the condition of the water is not suitable for drinking purpose. Industries and seasonal activities are responsible for the degraded quality of water in the study area. From WQI result is show that sample site S-4 suitable for drinking water while sample from S-1,S-2,S-3,S-5 and S-6 are very poor in WQI rating and unfit for drinking

\section{References}

Akinmosin, A., Osinowo, O. O. and Oladunjoye, M. A. 2009. Radiogenic components of the Nigeria Tars and Deposits. Earth Sci. Res. Jour. 13(1): 64-73.

APHA, 2012. "Standard Methods for the examination of Water and Wastewater", Lenore S C, Greenberg A E, Eaton A D,(Eds.), 20th Edition, American Public Health Association, NW, Washington, DC.

Bhadja P and Vaghela A. K. 2013. Assessment of physicochemical parameters and water quality index of reservoir water, International Journal of Plant, Animal and Environmental Sciences, 3(3): 89-95.

Bhutiani, R., Faheem, A., Tyagi, V. and Ram, K. 2018. Evaluation of water quality of River Malin using water quality index (WQI) at Najibabad, Bijnor (UP) India , Environment Conservation Journal, 19(1\&2): 191-201.

Bhutiani, R., Ram, K., Taygi, V., Ahamad, F. and Kaushik, P. 2018. Assesment of ground water qulity of Laksar block in district Haridwar, Uttarakhand, Environment Conservation Journal 19 (3): 123-128. 


\section{Bhutiani et al.}

Brown, R. M., McClelland, N.I., Deininger, R. A. and Tozer, R. G. 1970. A water quality index-do we dare? Water sewage works, 117: 339-343.

Chaterjee C. and Raziuddin M., 2002. Determination of water quality index (WQI) of a degraded river in Asanol Industrial area, Raniganj, Burdwan, West Bengal. Nature Environment and Pollution Technology 2: 181-189.

Cude, C. 2001. Oregon water quality index: A tool for evaluating water quality management effectiveness. Journal of the American Water Resources Association, 37: 125-137.

Jai M Paul, Arya V. S, Jesteena G, Reji K. J. and Sumitha K. S. 2014. Assessment of Ground Water Quality in Nellikkuzhy Panchayat of Kerala State, India, International Journal of Engineering Science Invention, 3(4): 21-28.

Khan, M. Y, Mir, S., Imtiyaz, A., Raja and Nazir A.W. 2012 Physico chemical analysis of River Jhelum (Kashmir).Global Journal of Science Frontier Research Interdisciplinary, 12: 325-330.

Khanna, D. R. and Bhutiani, R. 2008. Laboratory manual of water and Waste water Analysis. Daya Publishing House New Delhi -110002.

Kolhe Bharati G. and Shinde S. M. 2014. Study of Some Physico-Chemical Parameters of Godavari River Water at Ramkund, Nashik With Reference to Correlation Study. Indian Journal of research, 3(5): 1-3.

Kumar, S., Kumar, M., Kumar, A., Kumar, A., and Singh, A. K. 2017. Effect of Sugar Mill Effluents on Ground Water Quality Int.J.Curr.Microbiol.App.Sci , 6(12): 169-176.
Mandloi, A. 2014. Impact of industries on ground water quality by comparison between Hoshangabad (non industrial area) and Mandideep (industrial area), Bhopal (India), International Journal of Research in Engineering and Technology, 03 (12):144-146.

Milovanovic, M. 2007. Water quality assessment and determination of pollution sources along the Axios/Vardar River, Southeastern Europe. Desalination, 213: 159-173.

Ramakrishnaiah, C. R., Sadashivaiah, C. and Ranganna, G. 2009. Assessment of Water Quality Index for the Groundwater in Tumkur Taluk,Karnataka State, India , CODEN ECJHAOE-Journal of Chemistryhttp, 6(2): 523530.

Ruhela., M., Kumar, P., Tyagi, V., Ahamad, F. and Ram, K. 2018. Assessment of water quality of River Ganga at Haridwar with reference toWater Quality Index, Environment Conservation Journal 19 (3): 47-58.

Saxena, U. and Saxena, S. 2015. Correlation study on physicochemical parameters and quality assessment of ground water of Bassi tehsil of district Jaipur, Rajasthan, Suresh Gyan Vihar University. International Journal of Environment, Science and Technology, 1 (1): 78-91.

Shankar, B. S., Balasubramanya, N. and Reddy, M. T. 2007. Impact of industrialization on groundwater quality - a case study of Peenya industrial area, Bangalore, India.

Trivedy, R. K. and Goel, P. K. 1986. Chemical and Biological methods for water pollution studies. Environment Publication, Karad.

UNESCO. 2007. UNESCO water portal newsletter no.161: Water-related diseases. http://www.unesco.org/water/news/newsletter/161.shtml.

WHO, 2004. Changing history. Geneva, World Health Organiza- tion, 